\title{
Leczenie żywieniowe u chorych na nowotwory układów krwiotwórczego i chłonnego
}

\author{
Nutrition therapy for patients with myeloid \\ and lymphoid malignancies
}

\author{
Agata Lewandowska, Alicja Elżbieta Woźniak \\ Instytut Hematologii i Transfuzjologii, Warszawa
}

\begin{abstract}
Streszczenie
Pacjenci chorzy na nowotwory, zwtaszcza poddawani wysokodawkowanej chemioterapii lub/i radioterapii $w$ przebiegu nowotworów uktadów krwiotwórczego lub chtonnego, sa szczególnie narażeni na niedozywienie i powiktania wynikajacego $z$ tego stanu. Wszystkie dziatania stużace poprawie stanu odżywienia pacjentów moga pozytywnie wplywać na ich stan kliniczny, jakość zyycia oraz czas przeżycia. Poza stwierdzeniem niedożywienia istotne jest zwrócenie uwagi na aspekty determinujace możliwości kompensacyjne organizmu $i$ zapobiegajace niekorzystnym zmianom zwiazanym z rozwojem niedożywienia. Sa nimi w szczególności stopień odżywienia przed, w trakcie oraz po terapii ( $w$ tym określenie niedoborów pokarmowych) oraz możliwość spożywania, trawienia $i$ wchtaniania sktadników odżywczych. Celem poznania tych aspektów jest ustalenie szczegótowego $i$ zindywidualizowanego postepowania zywieniowego wspomagajacego podstawowa terapie przeciwnowotworowa.
\end{abstract}

Słowa kluczowe: żywienie, dieta, doustne odżywki, chemioterapia, chłoniak, białaczka

Hematologia 2016; 7, 3: 243-249

\begin{abstract}
Patients being treated for myeloid and lymphoid malignancies, particularly those by high dose chemotherapy and/or radiotherapy, are vulnerable to malnutrition and any complications so arising. All efforts for ensuring normal nutrition in such patients can benefit their clinical status/ loutcomes, quality of life and life expectancy. Besides identifying any malnutrition, attention should also be focused on how the body's mechanisms compensate and prevent adverse events from developing as a result of this condition. The most important of these aspects are the extent of patient nutrition before, during and after treatment, (and in defining malnutrition whenever it occurs), together with how nutrients are consumed, digested and absorbed. Determining such factors make it thereby possible to formulate a detailed nutritional plan tailored to the patient needs and thus support their basic cancer treatment.
\end{abstract}

Key words: nutrition, diet, oral nutritional support, chemotherapy, leukemia, lymphoma

Hematologia 2016; 7, 3: 243-249

Adres do korespondencji: Agata Lewandowska, Instytut Hematologii i Transfuzjologii, ul. Indiry Gandhi 14, 02-776 Warszawa, e-mail: alewandowska@ihit.waw.pl 


\section{Wprowadzenie}

Na stan odżywienia chorych na nowotwory, związany $z$ chorobą onkologiczną oraz prowadzonym leczeniem, wpływają przede wszystkim czynniki zależne od organizmu chorego, cech biologicznych nowotworu oraz odpowiedzi immunologicznej gospodarza na proces nowotworowy. Ponadto chemio- i radioterapia, zależnie od dawki oraz indywidualnej tolerancji, wywołuje wieloczynnikowe, często uciążliwe i trudne do opanowanie, działania niepożądane silnie korelujące ze stanem odżywienia. Najczęstszymi $z$ nich są zmniejszenie apetytu, zmiana smaku, suchość w jamie ustnej, zaburzenia jelitowe objawiające się wzdęciami, wymiotami, nudnościami lub biegunkami, a także zapalenie śluzówki jamy ustnej oraz przewodu pokarmowego [1, 2]. W konsekwencji stopień podaży diety oraz możliwość trawienia i wchłaniania poszczególnych składników pokarmowych ulegają obniżeniu.

\section{Patogeneza zaburzeń stanu odżywienia u chorych na nowotwory}

Jedną $z$ najważniejszych przyczyn wystąpienia zaburzeń odżywania u chorych na nowotwory jest zapalenie błon śluzowych, którego nasilenie zależy od rodzaju i dawki chemio- i radioterapii. $\mathrm{W}$ przypadku chorych poddawanych chemioterapii w standardowych dawkach problem ten rozwija się u 20-50\% osób, po wysokodawkowanej chemioterapii - u około 75\% chorych, a u chorych poddawanych leczeniu skojarzonemu (chemioi radioterapii), na przykład $z$ powodu nowotworów głowy i szyi, oraz u pacjentów po leczeniu mieloablacyjnym (MAC, myeloablative conditioning) poprzedzającym przeszczepienie krwiotwórczych komórek macierzystych (HSCT, hematopoietic stem cell transplantation) częstość ta wynosi około $85 \%$.
Do zapalenia błon śluzowych może również dochodzić w związku ze stosowaniem niektórych leków ukierunkowanych molekularnie (np. inhibitorów kinaz tyrozynowych). Większość wykorzystywanych leków dociera do błony śluzowej poprzez naczynia krwionośne, zaś metotreksat i etopozyd są wydzielane także do śliny i w związku $z$ tym bezpośrednio niszczą błonę śluzową.

W toku prowadzonej terapii przeciwnowotworowej uszkodzeniu ulegają komórki szybko dzielące się, co w przypadku błon śluzowych powoduje ograniczenie żywotności ich komórek macierzystych umiejscowionych powyżej błony podstawnej [3]. Czas ujawnienia się odczynu zapalnego jest funkcją czasu życia form dojrzałych, który w przypadku nabłonka wynosi 7-14 dni. Tempo cyklu zastępowania komórek zależy ponadto od dostępności składników energetycznych i odżywczych determinowanej przez wielkość rezerw organizmu oraz bieżącą podaż diety (enetralnie lub paraenteralnie).

Równolegle do rozwoju uszkodzeń śluzówki przewodu pokarmowego następuje ograniczenie funkcjonalności szpiku. Rezultatami są czasowa neutropenia, małopłytkowość oraz granulocytopenia, prowadzące do wzrostu ryzyka zakażeń, w tym septycznych, i krwawień [4]. Wtórnie do uszkodzenia nabłonka jelitowego oraz ograniczenia odpowiedzi immunologicznej w obrębie tkanki limfatycznej układu pokarmowego (GALT, gastrointestinal-associated lymphoid tissue) dochodzi do zaburzenia składu i funkcji mikroflory jelitowej, pogłębianego dodatkowo przez antybiotykoterapię. Dysbioza jelitowa wiąże się $z$ nasileniem biegunek i wzdęć, nadmiernym rozrostem mikroorganizmów patogennych, a także pogłębieniem niedoborów witamin produkowanych przez bakterie $\left(\mathrm{B}_{12}, \mathrm{~B}_{6}\right.$, $\mathrm{B}_{2}, \mathrm{~K}$, kwas foliowy) [5].

Triada powikłań — mucositis (patrz także tab. 1 [6]), neutropenia, dysbioza jelitowa - kwalifikuje pacjenta $z$ chorobą onkohematologiczną, zagrożo-

Tabela 1. Leki przyczyniające się do rozwoju mucositis (źródło [6])

Table 1. Drugs which contribute to the development of mucositis (source [6])

\begin{tabular}{|l|l|}
\hline Antagoniści kwasu foliowego & Metotreksat, ednotreksat \\
\hline Antracykliny & Idarubicyna, daunorubicyna, doksorubicyna \\
\hline Analogi pirymidyny & 5-fluorouracyl, kapecytabina, inhibitory cytozyny \\
\hline Związki alkilujące & Melfalan, busulfan, cyklofosfamid \\
\hline Związki platyny & Cisplatyna, karboplatyna \\
\hline Inhibitory topoizomerazy II & Etopozyd, irinotekan \\
\hline Analogi puryn & Fludarabina, kladrybina, 6-merkaptopuryna, 6-tioguanina \\
\hline $\begin{array}{l}\text { Antybiotyki o szerokim spektrum działania } \\
\text { na bakterie Gram- i Gram+ }\end{array}$ & Ciprofloksacyna \\
\hline
\end{tabular}


nego niedożywieniem, do niezwłocznego objęcia opieką interdyscyplinarnego zespołu żywieniowego i ustalenia dalszego postępowania żywieniowego.

Dodatkowym czynnikiem, sprzyjającym niedożywieniu u chorych na nowotwory, jest pobudzenie układu immunologicznego wtórne do choroby zasadniczej. Skutkuje to nasileniem syntezy białek ostrej fazy w wątrobie oraz produkcją czynników prozapalnych przez komórki układu odpornościowego, w tym wolnych rodników tlenowych (ROS, reactive oxigen species) $[7,8]$. Ich zwiększona i trwale utrzymująca się zawartość w osoczu działa hamująco na ośrodek regulacji głodu i sytości, znajdujący się w podwzgórzu, czego konsekwencją są zaburzenia łaknienia (anorexia) [9]. Uogólniony stan zapalny odgrywa także istotną rolę w rozwoju zaburzeń podstawowych procesów metabolicznych. W szlakach metabolizmu węglowodanów zostają nasilone glikoliza beztlenowa oraz glukoneogeneza, a także zwiększa się insulinooporność tkanek obwodowych. Zaburzenia w metabolizmie tłuszczów to przede wszystkim wzrost tempa lipolizy przy jednoczesnym ograniczeniu liponeogenezy [10-12]. W metabolizmie białek dochodzi tymczasem do nasilenia proteolizy białek mięśni szkieletowych. Uwolnione w tym procesie aminokwasy są wykorzystywane do syntezy glukozy de novo i białek ostrej fazy, a także białek nowotworowych [13, 14]. W przebiegu chorób onkohematologicznych nieswoistym objawem wzbudzenia kaskady systemowego stanu zapalnego są stany podgorączkowe i gorączka, czego następstwem jest zaburzenie procesów termoregulacji, w tym nadmierne pocenie się i utrata elektrolitów. W efekcie opisanych zmian metabolizm chorego zostaje przekierowany na szlaki kataboliczne, prowadząc do stopniowego wyniszczenia organizmu i zmniejszenia intensywności leczenia cytoredukcyjnego, a tym samym pogorszenia jego efektywności i rokowania dotyczącego przeżycia.

W warunkach zdrowia i choroby kontrola stanu zapalnego $\mathrm{w}$ organizmie zależy od aktywności systemu antyoksydacyjnego, na który składają się enzymy związane $z$ glutationem (kofaktorem jest selen), katalaza (kofaktorem jest mangan), dysmutaza ponadtlenkowa (kofaktorami są miedź/cynk lub mangan), enzymy naprawiające uszkodzone DNA (glikozylazy, nukleazy) oraz substancje egzogenne o działaniu antyoksydacyjnym (witaminy C i E, karotenoidy, flawonoidy) i endogenne (kwas moczowy, bilirubina, albuminy, przeciwutleniacze tiolowe, ubichinon) [15, 16]. Stężenia poszczególnych elementów tego systemu ulegają zaburzeniu $\mathrm{w}$ trakcie chemio- i radioterapii, między innymi w wyniku generowania w ich rezultacie dużych ilości ROS. Tym samym zapotrzebowanie pacjenta na selen, cynk, witaminę $\mathrm{C}$ i E, karotenoidy, przeciwutleniacze tiolowe czy ubichinon wzrasta. Przy braku możliwości ich bieżącej suplementacji wraz $z$ dietą oraz niewystarczających rezerwach organizmu mechanizmy antyoksydacyjne ulegają osłabieniu, czego skutkiem jest gromadzenie ROS oraz uszkadzanie struktur komórkowych i DNA.

Natężenie wyżej wymienionych zaburzeń zależy od dawki, rodzaju leku, poziomu jego toksyczności, intensywności leczenia cytoredukcyjnego oraz stosowanych terapii wspomagających. Celem często wprowadzanej w takich przypadkach steroidoterapiii, w ramach tak zwanej fazy przedleczenia (pretreatment), jest między innymi poprawa tolerancji leczenia cytostatycznego poprzez zahamowanie nadmiernego pobudzenia stanu zapalnego, ale stosowana dłużej może się przyczynić do negatywnego wpływu na anabolizm białek, powodując zahamowanie ich syntezy oraz nasilenie rozpadu, a także do nadmiernego rozpadu tłuszczów i nasilenia insulinooporności tkanek obwodowych [17]. Antybiotykoterapia (szczególnie o szerokim spektrum działania), poza wywoływaniem dysbiozy, może powodować również rzekomobłoniaste zapalenie jelit [18], a podawanie diuretyków — straty elektrolitów oraz witamin rozpuszczalnych w wodzie.

Dodatkowym elementem, który może wpływać na pogorszenie stanu odżywienia chorych na nowotwory układu krwiotwórczego, jest stosowanie lekkostrawnej diety ubogobakteryjnej. Celem jej podawania jest ograniczenie czynników podrażniających śluzówkę przewodu pokarmowego oraz poprawa wchłaniania składników pokarmowych. Dieta kuchenna, podawana drogą enteralną, zawiera wszystkie niezbędne makroi mikroskładniki, ale jednocześnie jest ona mieszaniną wysokoosmotyczną, o niepewnej jakości mikrobiologicznej oraz zmiennym składzie, wynikającym ze straty witamin i mikroelementów wraz z użyciem wysokich temperatur oraz dużej ilości wody do obróbki termicznej potraw. Tego typu żywienie, w sytuacji uszkodzenia śluzówki układu pokarmowego (szczególnie w ostrych stanach), $z$ dużym prawdopodobieństwem może prowadzić do wywołania biegunki osmotycznej, bolesnych kurczy jelit, wzdęć, pobolewania w podbrzuszu oraz innych dolegliwości związanych $z$ zaburzoną funkcją jelit. Ponadto, ze względu na wykluczenie produktów mlecznych, dieta ubogobakteryjna ogranicza możliwość dostarczenia korzystnych dla funkcjonowania przewodu pokarmowego bakterii kwasu mlekowego. Stosowanie preparatów pre- 
i probiotycznych, które jest korzystne u innych pacjentów, w przypadku chorych $z$ neutropenią może prowadzić do niekontrolowanego i niebezpiecznego wzrostu flory bakteryjnej.

Pacjenci $z$ chorobami onkohematologicznymi, poddawani wysokodawkowanemu leczeniu cytostatycznemu oraz radioterapii, wkutek ograniczenia lub całkowitego uniemożliwienia trawienia i wchłaniania oraz zmian metabolicznych w zakresie gospodarki energetycznej, stanowią grupę o wysokim ryzyku rozwoju umiarkowanego i ciężkiego niedożywienia jakościowego i ilościowego [19]. $\mathrm{Z}$ tego powodu istotne wydaje się postawienie pytania nie o to, 'czy', ale o to, 'jaką' metodą uzupełniać niedobory żywieniowe, by zabezpieczyć dostateczną ilość wszystkich składników odżywczych, niezbędnych do realizowania wzmożonego zapotrzebowania, biorąc pod uwagę indywidualną wydolność układu pokarmowego oraz dalszą strategię postępowania leczniczego.

\section{Zalecenia żywieniowe u chorych na nowotwory}

Dotychczas wytyczne Europejskiego Towarzystwa Żywienia Klinicznego i Metabolizmu (ESPEN, European Society for Clinical Nutrition and Metabolism) oraz Polskiego Towarzystwa Żywienia Pozajelitowego, Dojelitowego i Metabolizmu (POLSPEN) nie zawierały oddzielnego algorytmu postępowania żywieniowego dla pacjentów $z$ chorobami onkohematologicznymi. Wysokie ryzyko niedożywienia dotyczy zwłaszcza osób poddawanych wysokodawkowanej chemioterapii oraz napromienianiu całego ciała (TBI, total body irradiation). $Z$ tego powodu, jako postępowanie wspomagające, należy wykorzystywać wszystkie dostępne metody leczenia żywieniowego, łącznie $z$ zastosowaniem substancji immunomodulujących, w tym kwasów tłuszczowych omega-3 i glutaminy. Wybór rodzaju diety i drogi jej podaży powinien być zawsze zindywidualizowany i uwzględniać bieżące potrzeby, stan odżywienia oraz możliwości spożycia i przygotowania posiłków.

\section{Okres 1. - przygotowawczy}

do leczenia przeciwnowotworowego

Przed rozpoczęciem chemioterapii nie ma wskazań do obligatoryjnego podawania diety lekkostrawnej; należy polecać spożywanie wszystkich tolerowanych przez pacjenta pokarmów. W przypadku stwierdzenia ryzyka niedożywienia korzystne jest podawanie 1-3 sztuk doustnych suplementów pokarmowych (ONS, oral nutrition support). Stanowią one łatwo dostępne źródło energii oraz wszystkich niezbędnych makro- i mikroelementów, w tym tych o działaniu antyoksydacyjnym. Zawarte w nich dawki składników odżywczych są dostosowane tak, by nie doprowadzić do nadmiernego przekroczenia zapotrzebowania, nawet przy zaspokajaniu całkowitego zapotrzebowania na energię przez te preparaty. Ilość odżywek i ich skład należy dobierać do indywidualnego stopnia wydolności układu pokarmowego, nerek i wątroby.

W sytuacji braku tolerancji odżywek typu ONS korzystne może być wprowadzenie odżywek jednoskładnikowych. Są to preparaty o dużej tolerancji wchłaniania, zawierające tylko jeden makroskładnik diety — białko, tłuszcz lub węglowodany. Dzięki takim właściwościom możliwe jest dobranie tylko tego składnika, na który jest największe zapotrzebowanie w danym momencie choroby. Mieszaniny tłuszczów zawierają w swoim składzie oleje roślinne oraz są bogate w tłuszcze MCT (medium-chain triglyceride) zdolne do niezależnego wchłaniania $z$ jelita. Korzystną dawką są zwykle 3 miarki po $30 \mathrm{ml}$ takiej mieszaniny, która dostarcza około 400 kalorii. Preparaty białka i węglowodanów są dostępne głównie w formie proszku; jedna miarka dostarcza odpowiednio około 2,2 g czystego białka o właściwym profilu aminokwasowym bądź $4,8 \mathrm{~g}$ węglowodanów, głównie w formie polisacharydów. Preparaty jednoskładnikowe najlepiej podawać łącznie $z$ dietą kuchenną, jako jej wzbogacenie. Jeśli jednak pacjent odmawia dodawania ich do jedzenia, to można je podać po posiłku w formie rozpuszczonej w wodzie. Wadą preparatów jednoskładnikowych jest brak witamin i składników mineralnych oraz innych składników pokarmowych. W rezultacie w przypadku ich stosowania niezbędne może być wprowadzenie indywidualnie zaprojektowanej suplementacji, o zawartości ustalonej na podstawie obrazu klinicznego oraz niedoborów żywieniowych stwierdzonych za pomocą badań biochemicznych.

W przypadku wyniszczenia lub nasilonej anoreksji należy, jeśli jest to możliwe, odroczyć chemioterapię o 3-7 dni oraz włączyć leczenie żywieniowe. Takie postępowanie daje szansę na uzupełnienie bieżących niedoborów energetyczno-białkowych oraz witamin i mikroelementów.

\section{Okres 2. - w trakcie}

leczenia przeciwnowotworowego

Od pierwszej doby chemioterapii należy wprowadzić dietę lekkostrawną, bogatobiałkową, ubogobakteryjną, wzmocnioną ONS w liczbie 1-3/ /dobę. U pacjentów $z$ organomegalią, anoreksją lub szybką pełnością poposiłkową podstawą diety po- 
Tabela 2. Składniki odżywcze niezbędne dla chorych poddawanych chemioterapii (źródło [21])

Table 2. Nutrients necessary for patients undergoing chemotherapy (source [21])

\begin{tabular}{|l|l|}
\hline Grupa składników pokarmowych & Najważniejsze składniki z grupy \\
\hline Witaminy i prowitaminy & Witamina $\mathrm{D}$, witamina $\mathrm{B}_{12}$, witamina $\mathrm{C}$, witamina E, karotenoidy, witamina $\mathrm{A}$ \\
\hline Składniki mineralne & Selen, cynk, żelazo, magnez, wapń \\
\hline Aminokwasy i inne & Cysteina, glutation, karnityna \\
\hline Niezbędne nienasycone kwasy tłuszczowe & Omega 3 (EPA, DHA) \\
\hline $\begin{array}{l}\text { Składniki odżywcze o krótkim czasie } \\
\text { magazynowania }\end{array}$ & $\begin{array}{l}\text { Witamina } \mathrm{B}_{1}(4-10 \text { dni), witamina K (2-6 tygodni), kwas foliowy (3-4 miesią- } \\
\text { ce), witamina } \mathrm{B}_{6} \text { (ok. 1 miesiąc), witamina C (ok. 3 miesiące), witamina D } \\
(2-4 \text { miesiące), witamina } \mathrm{E}(6-12 \text { miesięcy) }\end{array}$ \\
\hline
\end{tabular}

winny być potrawy płynne lub o konsystencji papki $z$ dodatkiem ONS. W przypadku braku tolerancji preparatów wieloskładnikowych należy zastosować preparaty jednoskładnikowe.

W trakcie leczenia przeciwnowotworowego chorzy mogą być poddawaniu procedurom znieczulenia do zabiegów. Istotne jest w tych sytuacjach uwzględnienie rekomendacji protokołu kompleksowej opieki okołooperacyjnej w celu poprawy wyników leczenia (ERAS, enhanced recovery after surgery), w którym się jednoznacznie wskazuje na brak potrzeby głodzenia pacjentów przed większością operacji [20]. Przed zabiegami należy polecać spożywanie odżywek typu ONS, które pomagają między innymi zmniejszać insulinooporność po zabiegu operacyjnym. Niestety obecność w składzie niektórych preparatów acesulfamu K, służącego jako słodzik, może powodować (szczególnie u osób wrażliwych na ten składnik) oddawanie luźnych stolców.

\section{Okres 3. - nasilenia działań niepożądanych} po leczeniu przeciwnowotworowym

W okresie 3-5 dni od zakończenia chemioterapii objawy niewydolności układu pokarmowego nasilają się, narastają niechęć do jedzenia, znużenie, zaburzenia smaku i węchu, a także objawy uszkodzenia śluzówki przewodu pokarmowego. $\mathrm{W}$ tym czasie należy zmodyfikować rekomendacje żywieniowe i wziąć pod uwagę indywidualny stan kliniczny pacjenta. W trakcie 7-14 dni, kiedy objawy są najbardziej nasilone, zmniejsza się ilość spożywanego pokarmu, a trawienie i wchłaniane są zaburzone. Zmniejsza się również tolerancja w stosunku do potraw zawierających białko zwierzęce. Ze względu na wymienione problemy należy rozważyć wczesne włączanie żywienia parenteralnego $\mathrm{w}$ formie żywienia mieszanego - uzupełniającego żywienie enteralne. Uzupełniające żywienie pozajelitowe nie powinno przekraczać $60 \%$ całkowitego dobowego zapotrzebowania na energię, a jego podaż najlepiej prowadzić $z$ wykorzystaniem wkłucia centralnego, pamiętając o odstępie czasowym od podania leków przeciwnowotworowych. Monitoring żywienia uzupełniającego powinien być zgodny $z$ wytycznymi ESPEN i POLSPEN.

W ciągu 7-14 dni od zakończenia chemioterapii, kiedy działania niepożądane leczenia są najbardziej nasilone, ilość spożywanego pokarmu zmniejsza się jeszcze bardziej, a trawienie i wchłaniane ulegają zaburzeniu. Poza uzupełniającym żywieniem pozajelitowym należy rozważyć podawanie doustnych mieszanin zawierających 2-3 różne źródła tłuszczów, w tym oliwę $z$ oliwek, olej rybi lub olej sojowy. Korzystne jest również włączenie kwasów omega 3 oraz glutaminy, a także witamin i składników mineralnych (tab. 2) [21]. Obecnie na rynku są już dostępne mieszaniny zawierające w swoim składzie tłuszcze różnego pochodzenia, w tym mieszaniny oliwy $z$ oliwek (źródło jednonienasyconych kwasów tłuszczowych), oleju rybiego (źródło wielonienasycocnych kwasów tłuszczowych omega 3) oraz oleju sojowego [22]. Celem dodawania kwasów tłuszczowych omega 3 jest ograniczenie tworzenia prozapalnych tromboksanów, prostaglandyn i leukotrienów. Stwierdzono również, że powodują one redukcję stanu zapalnego $\mathrm{w}$ różnych schorzeniach przewodu pokarmowego, a w przypadku chorych na ostre białaczki szpikowe sprzyjają ograniczeniu występowania i nasilenia neutropenicznego zapalenia jelit [23].

Pozostałą ilość i rodzaj pokarmu pacjent powinien spożywać w formie diety lekkostrawnej, ubogobakteryjnej, uwzględniającej indywidualną tolerancję; najczęściej są to produkty $z$ białej mąki, kleiki ryżowe, kisiele oraz puree ziemniaczane. Korzyścią takiego postępowania jest stymulacja pasażu jelitowego oraz obniżenie ryzyka dysbiozy jelitowej, co jest szczególnie istotne $\mathrm{w}$ procesie regeneracji i gojenia błony śluzowej. W sytuacji 
Tabela 3. Rekomendacje Polskiego Towarzystwa Żywienia Pozajelitowego, Dojelitowego i Metabolizmu (POLSPEN) dotyczące przeciwwskazań do żywienia enteralnego (źródło [24])

Table 3. Recommendations of Polish Society for Parenteral, Enteral Nutrition and Metabolism (POLSPEN) about contraindications to enteral nutrition (source [24])

\begin{tabular}{|l|l|}
\hline Przeciwwskazania do żywienia enteralnego \\
\hline Upośledzenie wchłaniania z przewodu pokarmowego & $\begin{array}{l}\text { Niedrożność przewodu pokarmowego (porażenna } \\
\text { lub mechaniczna) }\end{array}$ \\
\hline Krwawienie z przewodu pokarmowego & Wstrząs \\
\hline Przeszkody w jelitach & Niedokrwienie jelit \\
\hline Zapalenie jelit & Uporczywe biegunki lub wymioty \\
\hline Neutropeniczne zapalenie jelit & Przetoki przewodu pokarmowego \\
\hline
\end{tabular}

masywnego zaplenia jelit (neutropenicznego lub septycznego), kiedy dochodzi do całkowitego braku tolerancji żywienia enteralnego, lub w przypadku niedrożności przewodu pokarmowego konieczne staje się wyłączne żywienie parenteralne (tab. 3) [24]. Żywienie to powinno być zgodne $z$ aktualnym zapotrzebowaniem na białko, tłuszcze, węglowodany oraz wszystkie witaminy i mikroelementy.

\section{Okres 4. - rekonwalescencji}

po leczeniu przeciwnowotworowym

Po zakończeniu terapii przeciwnowotworowej organizm pacjenta, nawet $\mathrm{w}$ przypadku prawidłowo prowadzonego leczenia żywieniowego, może wykazywać niedobory białkowo-energetyczne lub/i niektórych składników mineralnych i witamin. $\mathrm{Na}$ tym etapie opieki należy rozważyć suplementację wybranych składników pokarmowych w celu wsparcia procesów gojenia i rekonwalescencji oraz uzupełnienia rezerw organizmu. Dawki preparatów witaminowo-mineralnych oraz ich kompozycja powinny być dobrane tak, by realizować bieżące zapotrzebowanie pacjenta $-z$ uwzględnieniem stanu ogólnego oraz możliwości wchłaniania.

\section{Podsumowanie}

W trakcie długotrwałego procesu leczenia przeciwnowotworowego, zwłaszcza u chorych na nowotwory układów krwiotwórczego lub chłonnego poddawanych kolejnym cyklom chemioterapii, uzupełnianej radioterapią lub/i HSCT, dynamika zmian $\mathrm{w}$ zakresie trawienia i wchłaniania jest niezwykle duża przy jednoczesnym wzmożonym zapotrzebowaniu na makro- i mikroskładniki diety. Ponadto będące następstwem chemioterapii nudności i wymioty dodatkowo utrudniają spożywanie pokarmów. Patogeneza tych objawów oraz zasady profilaktyki przekraczają jednak ramy niniejsze- go opracowania i są przedstawione w osobnej publikacji [21]. Regularna i nieprzerwana podaż substancji odżywczych jest niezbędna, by wspierać możliwości kompensacyjne organizmu, chronić jego rezerwy i w ten sposób zapobiegać niedożywieniu. $Z$ tego powodu na każdym etapie terapii przeciwnowotworowej oraz po jej zakończeniu należy wykorzystywać wszystkie dostępne metody leczenia żywieniowego, łącząc je tak, aby były tolerowane przez pacjenta, a tym samym dostarczały wszystkich składników pokarmowych niezbędnych do prawidłowej pracy układu immunologicznego, funkcjonowania mechanizmów antyoksydacyjnych oraz uczestniczących w procesach gojenia i rekonwalescencji [25].

\section{Piśmiennictwo}

1. Sonis S.T. The pathobiology of mucositis. Nat, Rev. 2004; 30: $277-284$

2. Gibson R.J., Keefe D.M. Cancer chemotherapy-induced diarrhoea and constipation: mechanism of damage and prevention strategies. Support Care Cancer 2006; 14: 890-900.

3. Beutheu Youmba S., Belmonte L., Galas L. Methotrexate modulates tight junctions through $\mathrm{NF}-\kappa \mathrm{B}, \mathrm{MEK}$, and JNK pathways. J. Pediatr. Gastroenterol. Nutr. 2012; 54: 463-470.

4. Niscola P., Romani C., Cupelli L. Mucositis in patients with hematologic malignancies: an overview. Haematologica 2007; 92: 222-231.

5. Hattori M., Taylor T.D. The human intestinal microbiome: a new frontier of human biology. DNA Res. 2009; 16: 1-12.

6. Lalla R.V., Sonis S.T., Peterson D.E. Management of oral mucositis in patients with cancer. Dent. Clin. North Am. 2008; 52: 61-viii.

7. Skipworth R.J., Stewart D.F., Dejong C.H. Pathophysiology of cancer cachexia: much more than host-tumour interaction? Clin. Nutr. 2007; 26: 667-676.

8. Esfahani A., Ghoreishi Z., Nikanfar A. Influence of chemotherapy on the lipid peroxidation and antioxidant status in patients with acute myeloid leukemia. Acta Med. Iran. 2012; 5: 454-458.

9. Banks W.A. Anorectic effects of circulating cytokines: role of the vascular blood-brain barier. Nutrition 2001; 17: 434-437. 
10. Bing C., Russell S.T., Beckett E.E. Expression of uncoupling proteins- $1,-2$ and $-3 \mathrm{mRNA}$ is induced by an adenocarcinoma-derived lipid-mobilizing. Br. J. Cancer 2002; 86: 612-618.

11. Russell S.T., Hirai K., Tisdale M.J. Role of beta 3-adrenergic receptors in the action of a tumour lipid mobilizing factor. Br. J. Cancer 2002; 86: 424-428.

12. Kim H., Kataru R.P., Koh G.Y. Inflammation-associated lymphangiogenesis: a double-edged sword? J. Clin. Invest. 2014; 124: 936-942.

13. Whitehouse A.S., Tisdale M.J. Increased expression of the ubiquitin-proteasome pathway in murine myotubes by proteolysisinducing factor (PIF) is associated with activation of the transcription factor NF-kappaB. Br. J. Cancer 2003; 89: 1116-1122.

14. Busquets S., Saches D., Alvarez B. In the rat, tumor necrosis factor alpha administration results in an increase in both UCP2 and UCP3 mRNAs in skeletal muscle: a possible mechanism for cytokine-induced thermogenesis? FEBS Lett. 1998; 440: 348-350.

15. Grober U. Antiooxidant and other micronutrient in complementary oncology. Breast Care 2009; 4: 13-20.

16. Rahman K. Studies on free radicals, antioxidants and co-factors. Clin. Interv. Aging 2007; 2: 219-236.

17. Oray M., Abu Samra K., Ebrahimiadib N. Long-term side effects of glucocorticoids. Expert Opin. Drug Saf. 2016; 4: 457-465 .
18. Szuławska A., Czyż M. Molekularne mechanizmy działania antracyklin. Post. Hig. Med. Dośw. 2006; 60: 78-100.

19. Fijlstra M. Nutrient digestion and absorption during chemotherapy-induced intestinal mucositis in the rat. Doctoral thesis. University of Groningen, Groningen 2012.

20. Melnyk M., Rowan G.C., Black P. Enhanced recovery after surgery (ERAS) protocols: time to change practice? Can. Urol. Assoc. J. 2011; 5: 342-348.

21. Kalinka-Warzocha E., Warzocha K. Zasady profilaktyki nudności i wymiotów indukowanych chemioterapią i radioterapią u chorych leczonych $\mathrm{z}$ powodu nowotworów układów krwiotwórczego i chłonnego. Hematologia 2014; 5: 332-339.

22. Łyszkowska M. Wpływ emulsji tłuszczowych na układ immunologiczny. Post. Żyw. Klin. 2015; 35: 33-38.

23. Bukki J., Stanga Z., Firouzeh B.T. Omega-3 poly-unsaturated fatty acids for the prevention of severe neutropenic enterocolitis in patients with acute myeloid leukemia. Nutr. Cancer 2013; 65: 834-842.

24. Kłęk S., Jarosz J., Jassem J. Polskie Rekomendacje Żywienia Dojelitowego i Pozajelitowego w Onkologii — część II: żywienie drogą przewodu pokarmowego (żywienie dojelitowe). Onkol. Prakt. Klin. 2013; 6: 209-215.

25. Gröber U., Holzhauer P., Kisters K. Micronutrients in oncological intervention. Nutrients 2016; 3: 163. 